\title{
Magyar családorvosok egészségi állapotának, életmódjának vizsgálata
}

\author{
Mohos András dr. ${ }^{1}$ - Varga Albert dr. ${ }^{1}$ - Hargittay Csenge dr. ${ }^{2}$ \\ Csatlós Dalma dr. ${ }^{2}$ - Kalabay László dr. ${ }^{2}$. Torzsa Péter dr. ${ }^{2}$
}

${ }^{1}$ Szegedi Tudományegyetem, Általános Orvostudományi Kar, Családorvosi Intézet és Rendelő, Szeged

${ }^{2}$ Semmelweis Egyetem, Általános Orvostudományi Kar, Családorvosi Tanszék, Budapest

\begin{abstract}
Bevezetés: A családorvosok testi, lelki egészségi állapota hatással van a munkavégzésükre, a betegellátás minőségére, ezáltal a társadalom egészségmutatóira is. Az életmód pedig az egyik legjelentősebb, egészségi állapotot befolyásoló tényező. Célkitüzés: A vizsgálat célja a magyar háziorvosok egészségi állapotának és az azt befolyásoló életmódtényezőknek a felmérése.

Módszer: Keresztmetszeti vizsgálat. Kvantitatív, papíralapú felmérés családorvosok körében (n = 569, életkor $54 \pm 10$ év, nők 42\%).

Eredmények: A háziorvosok 61\%-a túlsúlyos vagy elhízott, 88\%-ának a vércukorszintje $\leq 5,5 \mathrm{mmol} / \mathrm{l}$. A résztvevők 50\%-a legalább heti rendszerességgel végez testmozgást, 20\%-uk egyáltalán nem. A háziorvosok 13\%-a dohányzik jelenleg, 5\%-a tekinthető nagyivónak. Enyhe fokú depressziós tünetegyüttes 19\%-uknál, közepes fokú 6\%-uknál, súlyos fokú 5\%-uknál fordult elő. A súlyos fokú kiégés mindkét nemben, mindhárom dimenzióban 18-39\% volt.

Következtetés: A magyar háziorvosok általános egészségi állapota nem mondható jobbnak sem a hazai nem orvos populációénál, sem a külföldi orvoskollégákénál. A magyar háziorvosok dohányzási mutatói kedvezőbbek a lakossági adatoknál, míg az alkoholfogyasztás terén kedvezötlenebb eredményeket kaptunk. Nemzetközi összehasonlításban, a káros szenvedélyek terén a hazai kollégák eredményei jónak tekinthetők. A depresszió és a kiégés gyakori előfordulása jelentős probléma a háziorvosok körében. Mentális egészségük monitorozása és gondozása a hatékony egészségügyi ellátórendszer kulcskérdése.
\end{abstract}

Orv Hetil. 2021; 162(12): 449-457.

Kulcsszavak: egészség, lelki egészség, családorvos, háziorvos, életmód

\section{Examination of the health status and health behaviors of Hungarian family physicians}

Introduction: General practitioners' somatic and mental health status have an impact on their work and the quality of care they provide and thus influence the health indicators of the society. Lifestyle is one of the most important influencing factors of health.

Objective: The study aims to assess the health status of Hungarian general practitioners and the lifestyle factors influencing it. Method: Cross-sectional study. Quantitative, paper-based questionnaire among general practitioners $(\mathrm{n}=569$, age $54 \pm$ 10 years, female $42 \%)$.

Results: $61 \%$ of family physicians are overweight or obese, $88 \%$ of them have blood glucose level $\leq 5.5 \mathrm{mmol} / 1.50 \%$ of the participants do exercise at least once a week, $20 \%$ do not take any exercise at all. $13 \%$ currently smoke, $7 \%$ are considered heavy drinkers. Mild, moderate and severe depression symptoms occurred in 19\%, $6 \%$ and $5 \%$ of them, respectively. A severe level of burnout syndrome was reported in $18-39 \%$ in both sexes, in all three dimensions.

Conclusion: The health status of Hungarian general practitioners is not better than that of the non-medical Hungarian population or than that of foreign colleagues. The smoking indicators of Hungarian doctors are more favorable than the Hungarian population data, while we obtained worse results in the field of alcohol consumption. In international comparison, the results of Hungarian colleagues in the field of smoking and alcohol consumption are good. The frequent occurrence of depression and burnout is a significant problem among family physicians. Monitoring and caring for their mental health is a key factor in the effective health care system.

Keywords: health, mental health, general practitioner, family physician, lifestyle

Mohos A, Varga A, Hargittay Cs, Csatlós D, Kalabay L, Torzsa P. [Examination of the health status and health behaviors of Hungarian family physicians]. Orv Hetil. 2021; 162(12): 449-457.

(Beérkezett: 2020. június 26.; elfogadva: 2020. augusztus 16.) 


\section{Rövidítések}

BDI $=($ Beck Depression Inventory $)$ Beck Depresszió Kérdőív; DSM $=$ (diagnostic and statistical manual of mental disorders) mentális betegségek diagnosztikai és statisztikai kézikönyve; ELEF = Európai lakossági egészségfelmérés; KSH = Központi Statisztikai Hivatal; MÁESZ = Magyarország átfogó egészségvédelmi szû́rôprogramja; PRIME-MD = (primary care evaluation of mental disorders) a mentális zavarok alapellátásának értékelése; OECD = (Organisation for Economic Co-operation and Development) Gazdasági Együttmúködési és Fejlesztési Szervezet; WHO = (World Health Organization) Egészségügyi Világszervezet

Generációk ismerik és teszik fel a kérdést tréfásan orvos ismerősüknek: „Doktor úr, a maga szíve sose fáj?” Azt már kevesebben tudják, hogy ez a mondat Melchior doktor dalának nyitó mondata Huszka Jenő és Fischer Sándor Szabadság, szerelem című daljátékában, melyet Jókai Mór Politikai divatok címú múve ihletett [1]. Talán a szerzők sem gondolták, hogy könnyed hangvételben ugyan, de milyen jelentős témát érintenek. Az egészségügy kifejezetten humánerőforrás-igényes ágazat, a benne dolgozók egészsége érték, amely közvetve kihatással van a komplett egészségügyi rendszer múködésére, ezáltal a lakosság egészségi állapotára. Mindemellett az orvosok példaként szolgálnak a betegek számára, így az orvostársadalom megbetegedéseinek, egészségkárosító szokásainak közvetve jelentős hatásuk lehet az egész társadalomra [2].

Az alapellátás az egészségügy egyik alappillére. Számos tanulmány igazolja, hogy az erős alapellátással rendelkező egészségügyi rendszerek hatékonyabban és jellemzően gazdaságosabban múködnek $[3,4]$. Így érdemes az alapellátó rendszer gerincét adó háziorvosok egészségi állapotát külön is tanulmányozni, ám eddig kevés, célzottan rájuk vonatkozó kutatás történt hazánkban.

Az egészség dinamikusan változó állapot, így kiemelt jelentőségü azon tényezők ismerete, amelyek befolyásolhatják. Ezen tényezők bemutatására alkalmas az 1974ben bemutatott Lalonde-modell, amely négy faktort azonosít, melyek eltérô mértékben befolyásolják az egészségi állapotot: genetikai-biológiai tényezők (27\%), környezet (19\%), életmód (43\%), illetve egészségügyi ellátás (11\%) [5]. A felsorolt arányszámok területenként és időszakonként eltérőek lehetnek, azonban a fentiek érvényességét igazolja az Egészségügyi Világszervezet (WHO) 2010. évi egészségfejlesztési stratégiájának modellje, amely szintén a felsorolt négy tényezőt veszi alapul [6]. A hazai egészségfelmérések is a helytelen táplálkozást, a mozgásszegény életmódot, a túlsúlyt, a dohányzást és a szeszesital-fogyasztást tartják számon fó egészségrizikó-faktorként [7,8].

Az egészségügyi dolgozók, orvosok egészségi állapotával, életmódi szokásaival, az orvosi hivatás egészségre gyakorolt hatásával foglalkozó nemzetközi vizsgálatok alapján a fokozott munkahelyi stressz és a jelentős munkahelyi terhelés jelentős rizikófaktor. Az elhízás - mint jelentős cardiovascularis rizikófaktor - a társadalom egészéhez hasonlóan az orvospopulációban is jelentős probléma. Az orvosok dohányzási szokásai jellemzően kedvezőbbek az általános társadalmi adatoknál, míg az alkoholfogyasztási szokások sok esetben kedvezőtlenebbek. További probléma, hogy az orvosok sok esetben nem fordítanak kellő figyelmet saját egészségi állapotukra, a megfelelő szưrési, gondozási tevékenységekben páciensként való részvételre [9-15].

A szomatikus betegségek mellett nem szabad elfeledkezi a kollégák lelki egészségéról, mentális állapotáról sem. Az egészségügyi ellátórendszerben elfoglalt speciális szerepük következtében (nagyszámú orvos-beteg találkozás, jelentős fizikai, pszichés, mentális igénybevétel) a kiégés szempontjából, a depresszió, valamint a szorongásos kórképek kialakulása kapcsán az egyik legveszélyeztetettebb a háziorvoslás. A kiégés előfordulása az elmúlt évtizedekben folyamatosan növekszik, valamint igen korán jelentkezik a gyógyítók pályafutása során [16-19]. Az egészségügyi dolgozók kiégése az ellátás valamennyi szereplőjére hatással van: amellett, hogy az orvosok, szakdolgozók egészségi állapotát közvetlenül befolyásolja, közvetve - az ellátás minőségén keresztül a betegek gyógyulására, valamint elégedettségére is kihat, továbbá befolyásolja a munkakörnyezetet is. A kiégés szomatikus és mentális megbetegedésekhez vezethet. A kiégésszindrómában szenvedők körében gyakoribb a koffein- és az alkoholfüggőség, a dohányzás és a drogfogyasztás $[20,21]$. Több tanulmány igazolja a kiégés negatív hatását a betegellátás minőségére mind az orvosok, mind a szakdolgozók szintjén [22, 23 ].

\section{Vizsgálatunk célkitúzése}

A magyar családorvosok egészségügyi állapotának felmérése, különös tekintettel az alábbi tényezők vizsgálatára:

- elhízás,

- vércukorszint,

- vérkoleszterinszint,

- vérnyomásmérési szokások, magasvérnyomás-betegség előfordulása,

- testmozgás,

- dohányzási szokások,

- alkoholfogyasztási szokások,

- depresszió,

- kiégés.

\section{Módszer}

A részt vevő családorvosok egészségi állapotának felmérése a Semmelweis Egyetem Családorvosi Tanszékének munkatársai által összeállított kérdőív felhasználásával történt. A papíralapú kérdőíveket a háziorvosok számára a Tanszék által 2016. szeptember és 2019. március között szervezett, kötelező szinten tartó előadás-sorozatokon személyesen adtuk át. A válaszadás önkéntes alapon, anonim módon történt. 
A kérdőív első részében a résztvevők demográfiai adataira (nem, életkor, családi állapot, a praxis adatai) kérdeztünk rá. A speciálisan a családorvosok számára összeállított kérdőív a továbbiakban 15 témakört vizsgált (testtömegindex; vérnyomás; vércukorszint; vérkoleszterinszint; krónikus betegség előfordulása; rendszeres gyógyszerszedés; depresszió; kiégés; az élettel való elégedettség; dohányzási szokások; alkoholfogyasztási szokások; testmozgás; alvási szokások; az obstruktív alvási apnoéhez kapcsolódó ismeretek; az elhízáshoz mint betegséghez kapcsolódó ismeretek). Az adatok megadása önbevallás alapján történt, méréseket nem végeztünk, orvosi dokumentációt nem kértünk. A depresszió előfordulásának és mértékének mérésére a rövidített Beck Depresszió Kérdőívet (BDI) alkalmaztuk. Ennek segítségével a vizsgáló a felmérésben szereplő személy által adott válaszokat l-től (egyáltalán nem jellemző) 4-ig (teljesen jellemző) tartó skálán pontozza külön-külön, majd az ezekből kapott összesített pontszám alapján a vizsgált egyénre jellemző depressziós állapot mértékét határozhatja meg (normál: 0-9 pont; enyhe: 10-18 pont; közepesen súlyos: 19-25 pont; súlyos: 26 pont feletti érték). A családorvosok közötti kiégés (burnout) előfordulásának arányát és fokát a Maslach Burnout Kérdőívvel mértük fel. A 22 állítást tartalmazó kérdőív a kiégés három dimenzióját vizsgálja: érzelmi kimerülés (9 állítás), deperszonalizáció (5 állítás), teljesítménycsökkenés (8 állítás). A résztvevők hétfokozatú Likert-skálán (0-6) értékelik, hogy milyen gyakran észlelik az egyes állításokat. Az egyes dimenziók összpontszámának harmadolásával három osztályt - alacsony, közepes és súlyos - alakítottak ki. Súlyos fokú emocionális kimerülésről 27 pont felett, deperszonalizációról 10 pont felett, teljesítménycsökkenésről 33 pont alatt beszélünk.

Felmérésünkben összesen 569, hazánkban praktizáló családorvos adatait dolgoztuk fel, a válaszadási arány $62 \%$ volt. A teljes mintában a férfiak aránya $58 \%$ volt. A felmérésben részt vevő családorvosok összesített átlagéletkora $54 \pm 10$ év volt. A nők átlagéletkora $53 \pm 9$ év, a férfiaké $55 \pm 9$ év volt. A kérdőívek statisztikai elemzését MS Excel 2007 (Microsoft Corporation, Redmond, WA, Amerikai Egyesült Államok) és SPSS 23.0 statisztikai elemzőprogram (IBM Corporation, Armonk, NY, Amerikai Egyesült Államok) segítségével végeztük.

A vizsgálatunkban részt vevő háziorvosok eredményeit két csoporttal hasonlítottuk össze. A teljes hazai népességet reprezentáló lakossági felmérések eredményeivel, valamint más országokban tevékenykedő orvos-, háziorvos-kollégák eredményeivel. Az első csoporttal való öszszevetés az azonos kulturális, társadalmi közeg, a második csoporttal való a tevékenységük hasonló jellege, a hasonló munkahelyi hatások miatt érdekes. A hazai lakossággal való összehasonlítás során igyekeztünk minél frissebb, reprezentatív felmérések adatait, illetve nagy elemszámú publikációk adatait felhasználni. Ahol lehetőség adódott rá, ott a teljes lakosság mellett kiemelten a felsőfokú végzettséggel rendelkezőkkel végeztük az ösz- szehasonlítást. Munkánk során több, eltérő módszertannal és kérdéskörrel foglalkozó lakossági felmérés eredményeit is felhasználtuk:

- Statisztikai Tükör: Egészségi állapot és egészségmagatartás, 2016-2017 [7].

- Egészségjelentés 2016: Információk a népegészségügyi beavatkozások célterületeinek azonosításához a nem fertőző betegségek és az egészségmagatartási mutatók elemzése alapján [8].

- Társadalmi helyzetkép 2010 [24].

- „Magyarország átfogó egészségvédelmi szûrőprogram”-jának (MÁESZ) 2016. évi és 2010-2016 közötti összefoglaló adatai.

- A 2014-ben végrehajtott Európai lakossági egészségfelmérés eredményei. Összefoglaló adatok. (A 2019ben végzett lakossági egészségfelmérés adatai még nem érhetők el, 2020 őszén küldik el őket az Eurostatnak jóváhagyásra.)

A nemzetközi adatokat nyilvánosan elérhető adatbázisokból (például OECD-adatbázis), valamint releváns publikációkból szereztük.

\section{Eredmények}

A megkérdezett háziorvosok $(\mathrm{n}=569$ ) 39\%-a normál testtömegú, 40\%-a túlsúlyos, 15\%-a elhízott, 6\%-a pedig kórosan elhízott volt (1. ábra).

A háziorvosok $(n=569)$ 36\%-ának koleszterinszintje volt a normáltartományban, 42\%-ának 5 és $5,9 \mathrm{mmol} / \mathrm{l}$ között volt, míg 22\%-ának $6 \mathrm{mmol} / 1$ felett (2. ábra).

$\mathrm{Az}$ éhomi vércukorszint a vizsgálatban részt vevő családorvosok (n = 569) 88\%-ánál $\leq 5,5 \mathrm{mmol} / 1$ volt, 9\%-ánál 5,6 és 6,9 mmol/liter közötti, 3\%-ánál pedig elérte vagy meghaladta a $7 \mathrm{mmol} /$ litert (3. ábra).

A válaszadók $(n=569)$ 65\%-a legalább havonta, 25\%uk legalább félévente megméri a vérnyomását. 7\% több mint egy éve nem mérte a vérnyomását, további 3\%

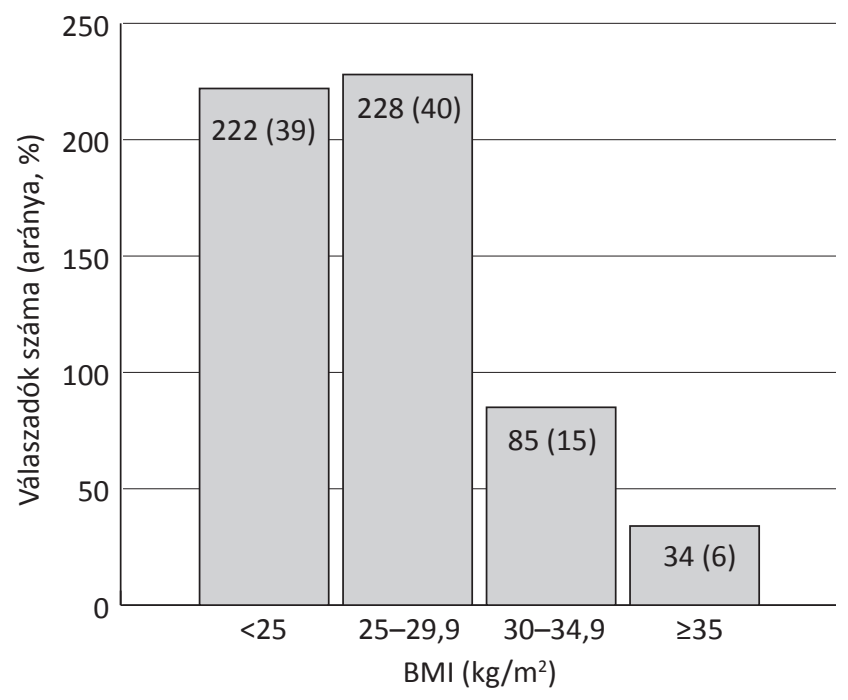

1. ábra $\mid$ A háziorvosok testtömegindex (BMI) szerinti megoszlása $(\mathrm{n}=569)$ 


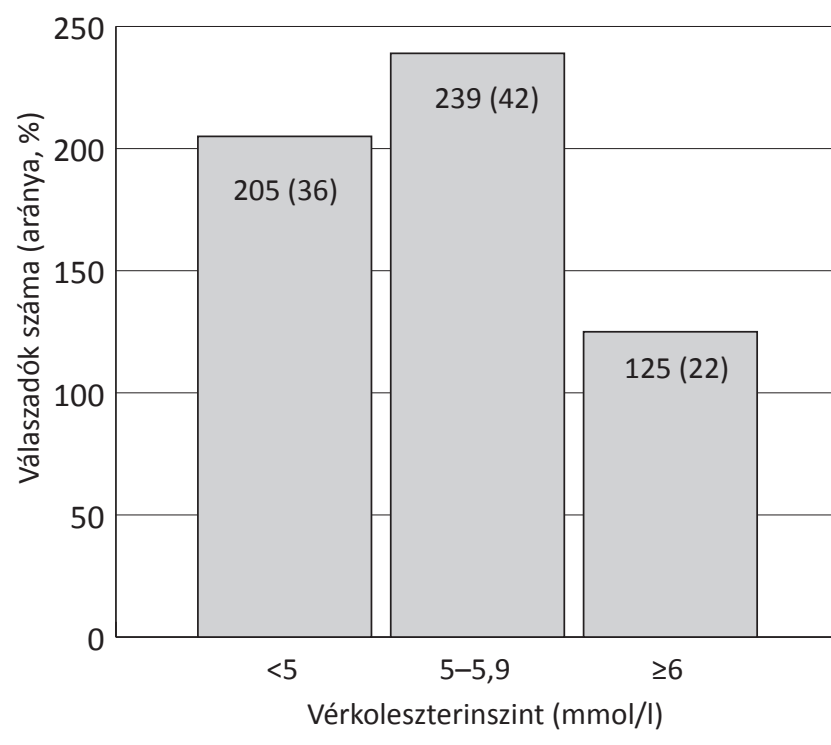

2. ábra $\mid$ A háziorvosok vérkoleszterinszintje $(\mathrm{n}=569)$

pedig egyáltalán nem tudja az utolsó mérés időpontját. A családorvosok válaszai alapján 94\%-uk vérnyomása 140/90 Hgmm alatt volt, míg 6\% esetén a systolés és a diastolés vérnyomásértékek közül legalább az egyik meghaladta a $140 \mathrm{Hgmm}$-es, illetve $90 \mathrm{Hgmm}$-es normálértéket (4. ábra).

Aktív testmozgást a válaszadók $(\mathrm{n}=500)$ 20\%-a egyáltalán nem, 30\%-uk kevesebb mint heti egy alkalommal, $22 \%$-uk hetente egyszer, $28 \%$-uk pedig hetente többször is végez (5. ábra).

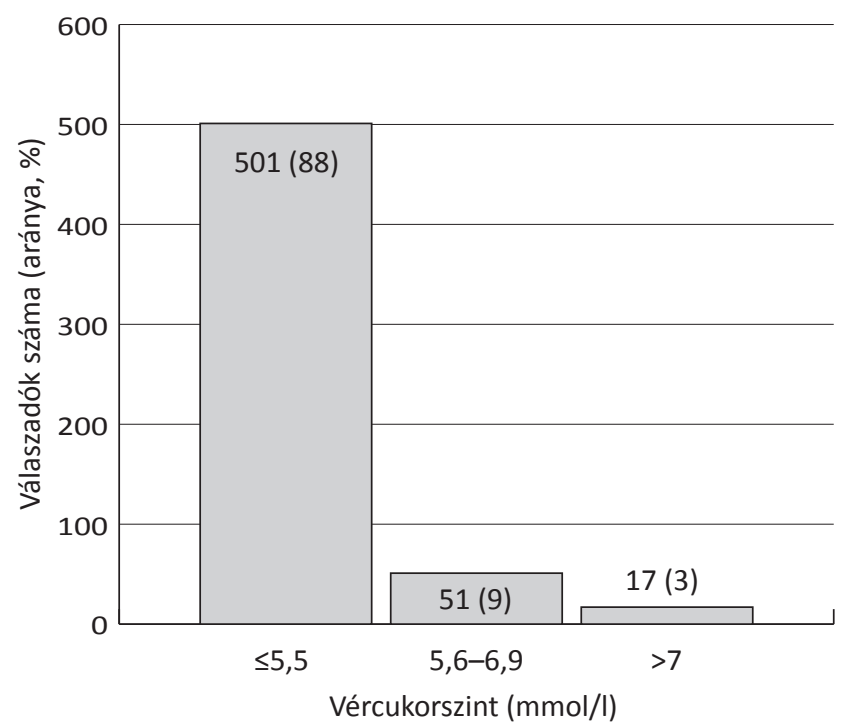

3. ábra |A háziorvosok éhomi vércukorszintje $(\mathrm{n}=569)$

A családorvosok $(\mathrm{n}=556) 58 \%$-a sohasem dohányzott; 29\%-uk korábban dohányzott, de mára már leszokott, 13\%-uk pedig ma is aktív dohányos (6. ábra).

Alkoholt a háziorvosok $(\mathrm{n}=434) \quad 16,5 \%$-a hetente négy vagy annál is több alkalommal, 20\%-uk hetente kéthárom alkalommal, 21,5\%-uk havonta kétszer-négyszer, 29\%-uk havonta egyszer vagy még annál is ritkábban, 13\%-uk pedig sohasem fogyaszt. A válaszadók $(\mathrm{n}=372)$ $78 \%$-a hetente 8 egységnyinél kevesebb alkoholt fogyaszt, 14\%-uk 8,1-15 egység alkoholt iszik, 3\%-uk heti alkohol-
Milyen gyakran méri a vérnyomását?

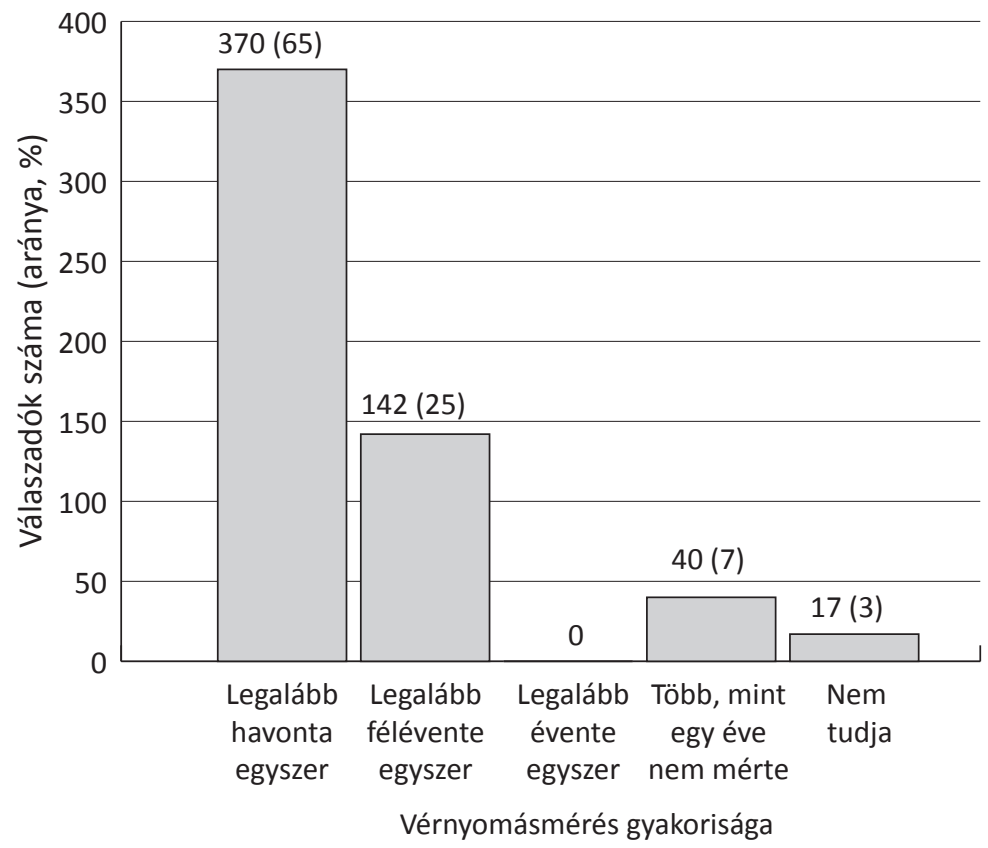

Mennyi volt a vérnyomása az utolsó mérés alkalmával?

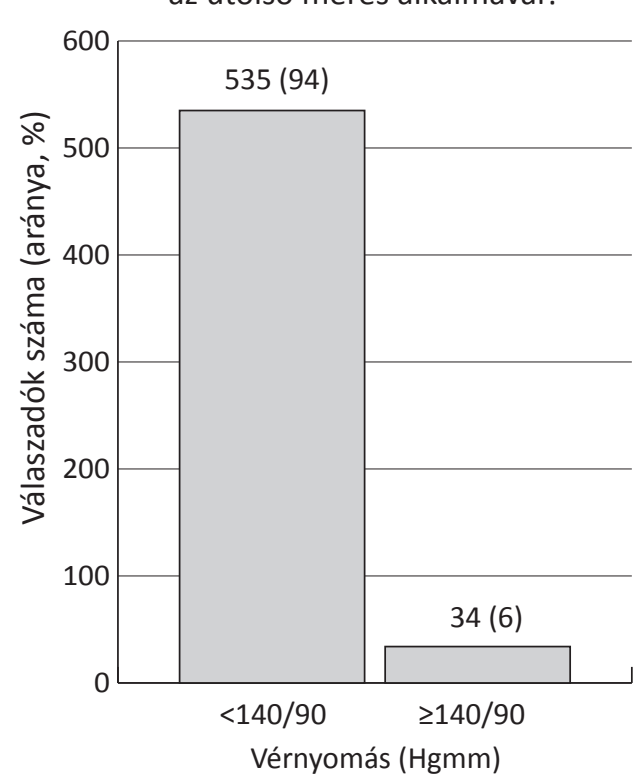

4. ábra

| A háziorvosok vérnyomásmérési szokásai $(\mathrm{n}=569)$ 


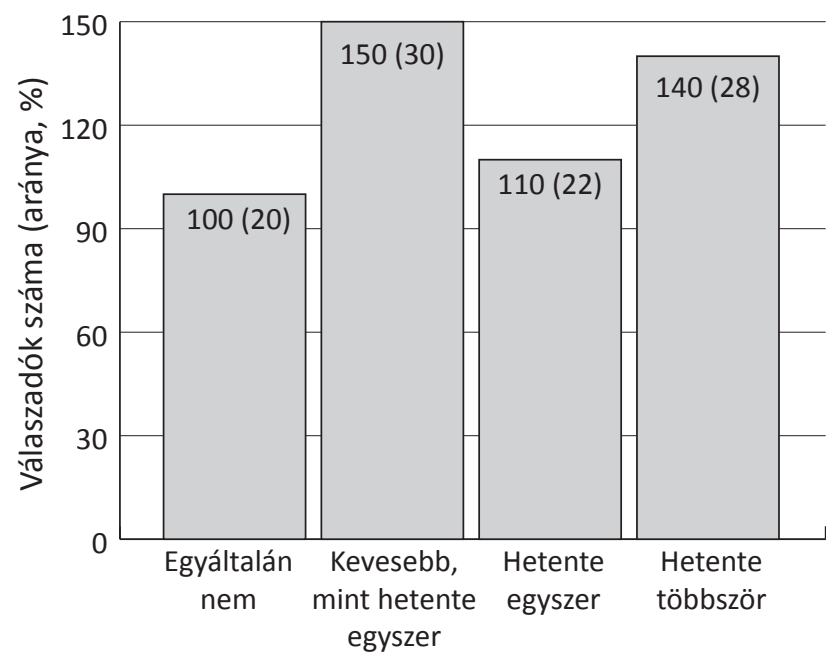

Aktív testmozgás gyakorisága

fogyasztása pedig 15,1-21 egységnyire rúg. A családorvosok 5\%-a 21 egységnél több alkoholt fogyaszt heti rendszerességgel, vagyis nagyivónak tekinthető (7. ábra).

A felmérésben szereplő családorvosok körében $(\mathrm{n}=$ 417) az enyhe fokú depressziós tünetegyüttes (BDI: 10-18 pont) 19\%-ban jelentkezett, a közepes fokú depressziós tünetegyüttes (BDI: 19-25 pont) 6\%-uknál, míg a súlyos fokú depressziós tünetegyüttes (BDI: $\geq 26$ pont) 5\%-uk esetében volt kimutatható ( 8 a ábra).

Nem találtunk szignifikáns különbséget a kiégés szempontjából a két nem között. Közepes fokú emocionális kimerülés a férfi családorvosok $(n=200) 22 \%$-ánál, a női családorvosok ( $\mathrm{n}=288$ ) 18\%-ánál fordult elő, míg súlyos fokú emocionális kimerülés a vizsgálatban a két nemnél $23 \%$, illetve $27 \%$ volt. Közepes fokú deperszonalizáció a

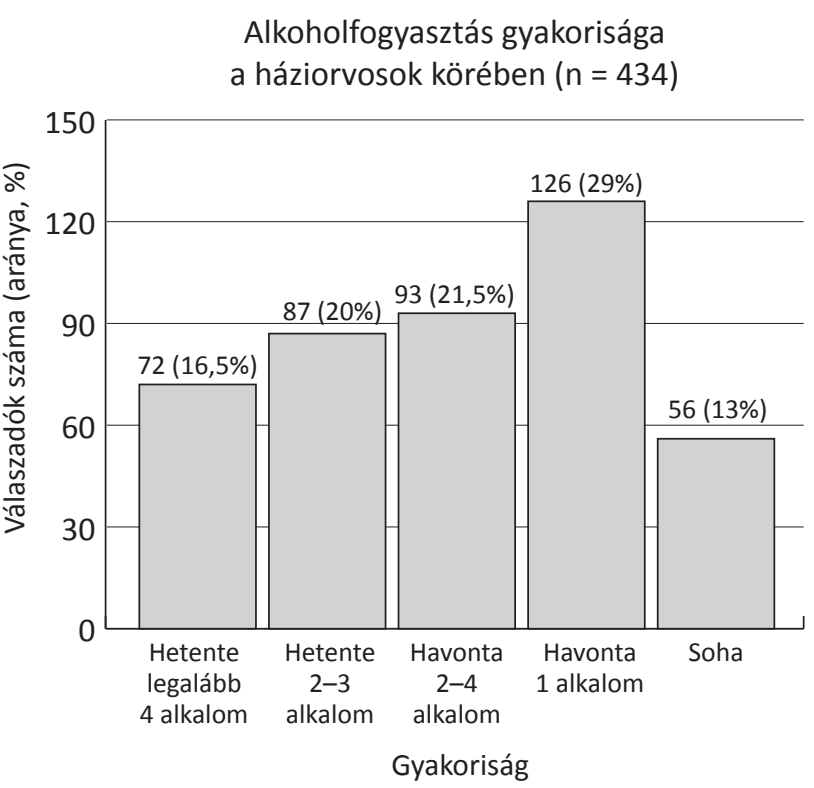

7. ábra | A háziorvosok alkoholfogyasztási szokása

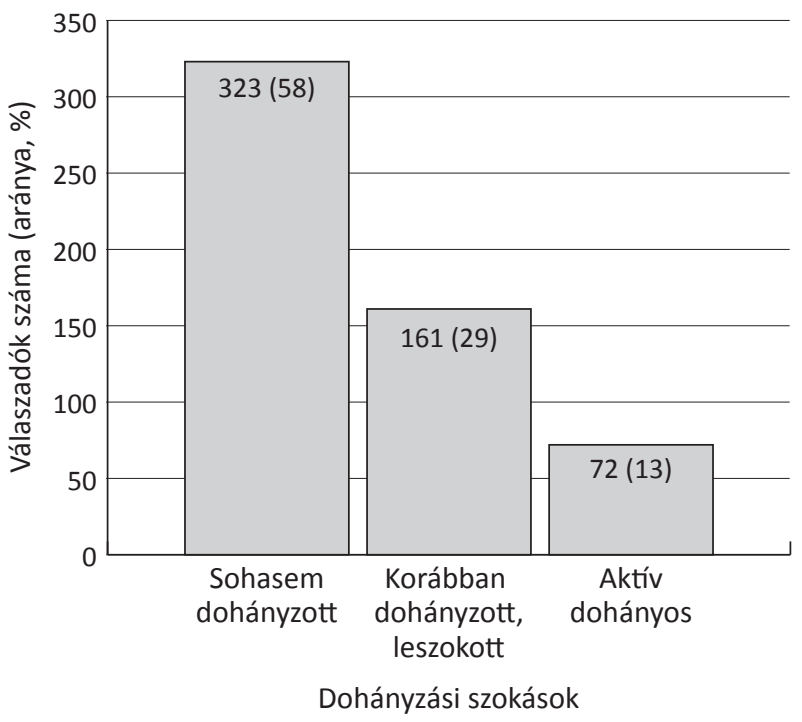

6. ábra A háziorvosok dohányzási szokásai $(\mathrm{n}=556)$

férfi családorvosok 15\%-ánál, a női családorvosok 9\%ánál volt regisztrálható, míg súlyos fokú deperszonalizáció a férfiak 23\%-ánál és a nők 18\%-ánál. Közepes fokú munkahelyi teljesítménycsökkenést a férfi válaszadók 13\%-ánál és az orvosnők 23\%-ánál találtunk. Súlyos fokú teljesítménycsökkenés a férfi háziorvosok 39\%-ánál és a női háziorvosok 32\%-ánál volt diagnosztizálható (1. táblázat).

\section{Megbeszélés}

Az egészség nem pusztán egészségügyi kérdés, számos olyan tényező is befolyásolja, amelyre az egyén is befolyással van. A kockázati tényezőkkel magyarázható egészségveszteség túlnyomó része (79\%) összefügg a

A háziorvosok által hetente elfogyasztott alkoholmennyiség ( $n=372$ )

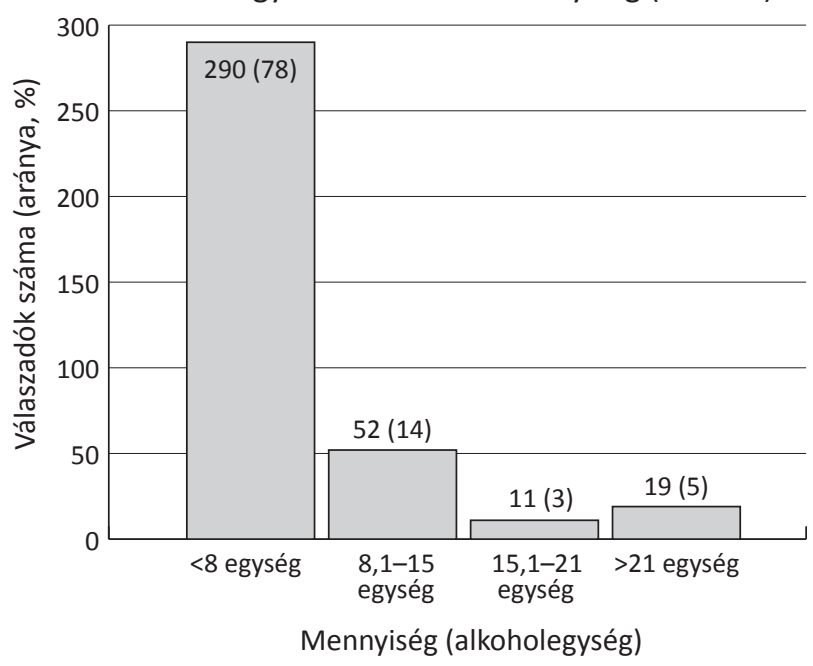




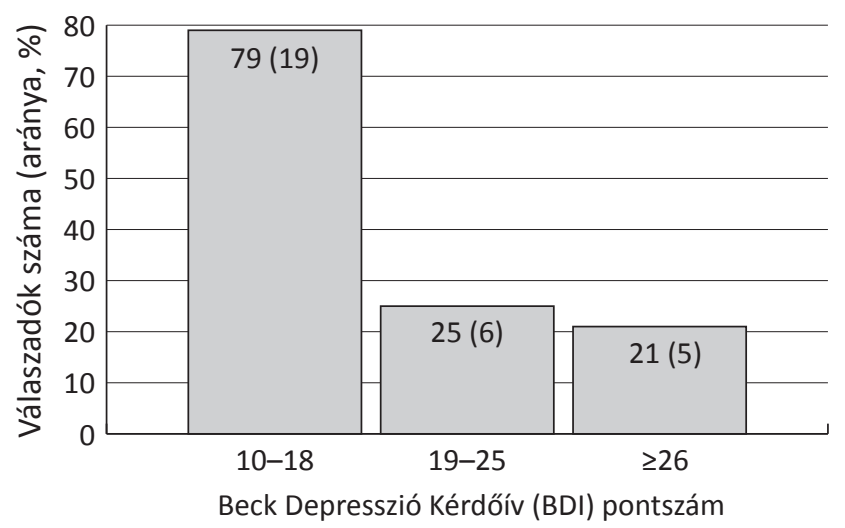

\begin{tabular}{l|l} 
8. ábra & Depressziós tünetek előfordulása a háziorvosok körében
\end{tabular} $(\mathrm{n}=417)$

1. táblázat |A kiégés egyes dimenzióinak előfordulása

\begin{tabular}{lllll}
\hline A kiégés dimenziója & $\begin{array}{l}\text { A kiégés } \\
\text { foka }\end{array}$ & $\begin{array}{l}\text { Férfi } \\
\%[\mathrm{n}]\end{array}$ & $\begin{array}{l}\text { Nó } \\
\%[\mathrm{n}]\end{array}$ & $\begin{array}{l}\text { Összesen } \\
\%[\mathrm{n}]\end{array}$ \\
\hline Emocionális & Alacsony & $55[110]$ & $55[158]$ & $55[268]$ \\
kimerülés & Közepes & $22[44]$ & $18[52]$ & $20[98]$ \\
& Súlyos & $23[46]$ & $27[78]$ & $25[122]$ \\
\hline Deperszonalizáció & Alacsony & $62[124]$ & $73[210]$ & $68[332]$ \\
& Közepes & $15[30]$ & $9[26]$ & $12[59]$ \\
& Súlyos & $23[46]$ & $18[52]$ & $20[98]$ \\
\hline Teljesítménycsök- & Alacsony & $48[96]$ & $45[130]$ & $46[224]$ \\
kenés & Közepes & $13[26]$ & $23[66]$ & $20[98]$ \\
& Súlyos & $39[78]$ & $32[92]$ & $34[166]$ \\
\hline
\end{tabular}

$\mathrm{n}=488$ fö, férfi: 200 fö, nő: 288 fö

viselkedéssel, ezért fontos a népegészségügyi tervezés során az egészségmagatartás megváltoztatására irányuló beavatkozások előtérbe helyezése [8]. Az életmód szerepe, a táplálkozási, mozgási szokások, a káros szenvedélyek, a munkahelyi körülmények, valamint az alvási szokások is kiemelt jelentőséggel bírnak az egészségi állapot kapcsán.

Az elhízás mint önálló kórkép - valamint több, jelentôs mortalitással járó betegség (cardiovascularis, daganatos betegségek) rizikófaktoraként - jelentős népegészségügyi problémát jelent. Önbevallás alapján, a vizsgálatunkban részt vevő háziorvosok alig több mint egyharmadának a testtömegindexe található a normáltartományban (1. ábra). A Központi Statisztikai Hivatal (KSH) felmérése szerint 2017-ben a 15 év feletti magyar lakosság több mint egyharmada volt túlsúlyos, közel egyötöde elhízott, az együttes arány $55,5 \%$ volt [7]. Ez az adat lényegében megfelel a vizsgálatunkban találtaknak. A túlsúly kialakulását jelentősen befolyásolja a társadalmi-gazdasági helyzet. A KSH egy korábbi felmérése alapján a felsőfokú végzettségűek körében a legalább túlsúlyosak aránya 45\% [24]. Ezek alapján a hasonló végzettségú csoporttal összehasonlítva a részt vevő házior- vosok között gyakoribb volt a túlsúly és az elhízás előfordulása. Nemzetközi összehasonlításban szintén kedvezőtlen a kép. A vizsgálatban részt vevők körében gyakoribb volt a túlsúly és az elhízás előfordulása, mint külföldi kollégáiknál. A brit orvosok 29,1\%-a túlsúlyos, 19,5\%-a elhízott [9]. Katalán orvosok körében 31,7\% volt a túlsúly, 4,8\% az elhízás előfordulási aránya [10]. Az Amerikai Egyesült Államokban a kardiológusok, valamint kanadai orvosok körében egyaránt $8 \%$ volt az elhízás előfordulási gyakorisága $[25,26]$.

A háziorvosok mintegy ötöde válaszolta, hogy utolsó mérése alkalmával magasabb volt a koleszterinszintje, mint $6 \mathrm{mmol} / \mathrm{l}, 64 \%$-uknak $5 \mathrm{mmol} / \mathrm{l}$ feletti a koleszterinértéke. A lakosság körében a MÁESZ keretében végzett szürővizsgálatok során nőknél 31,6\%-ban, férfiaknál $40,8 \%$-ban fordult elö $5,2 \mathrm{mmol} / \mathrm{l}$ feletti koleszterinérték [27]. Ezek alapján kijelenthető, hogy a háziorvosok körében feltehetőleg nem alacsonyabb a lipoproteinanyagcsere betegségeinek prevalenciája, mint a nem háziorvos populációban. Olasz kardiológusok 35\%-ánál fordult elő magas koleszterinszint [11]. Egy friss kutatás szerint kínai orvosok 13,6\%-ának volt emelkedett a koleszterinszintje [12]. Brit orvosok körében a dyslipidaemiák előfordulása $14,4 \%$ volt, ami a kínai adatokhoz hasonlóan kedvezőbb a mi eredményeinknél [9].

A cukorbetegség hazai prevalenciája 9,3\% a 20-79 éves korosztályban [28]. Vizsgálatunkban az éhomi vércukorszint a családorvosok 12\%-ánál haladta meg a normáltartományt, 9\%-uk esetén kóros éhomi vércukorszintről beszélhetünk. A regisztrált betegségkódok és a mért eredmények között egyértelmú párhuzam ebben az esetben sem húzható, ám a szénhidrát-anyagcsere rendellenességeinek előfordulása feltehetôleg nem ritkább a vizsgált háziorvosok körében, mint az átlagpopulációban. Olasz kardiológusok körében a cukorbetegség előfordulása 3,2\%, míg brit kollégáik között 3,5\% volt [9, 11] - ezek az adatok kedvezóbbek a felmérésünk adatainál.

A dohányzás hazánkban és az egész világon egyaránt az egyik legjelentősebb népegészségügyi probléma és a legfőbb megelőzhető haláloki tényező. A WHO becslése szerint a dohányzás miatt évente körülbelül hatmillióan vesztik életüket világszerte [29]. Az Európai Unión belül országunk a napi dohányosok arányát tekintve az elsók között van [30]. A dohányzás a magyar lakosság egészségveszteségének 14\%-áért volt okolható [8]. Felmérésünkben kisebb arányban voltak az aktívan dohányzó családorvosok, mint a teljes hazai populációban (13\% vs. 29\%), míg a dohányzást már abbahagyók aránya magasabb volt (29\% vs. 19\%), azaz a háziorvosok dohányzási szokásaival kapcsolatos adatok kedvezőbbek az átlagpopulációéinál [31]. Nemzetközi vizsgálatok alapján Európa legnagyobb részén az átlagpopulációhoz képest a háziorvosok lényegesen kisebb hányada dohányzik. A dohányzó orvosok aránya Észtországban 6,7\%, Lengyelországban 7,8\%, Szaúd-Arábiában 16,1\% volt [13, 32, 33]. Egy korábbi összefoglaló tanulmányban, a legtöbb 
országban a dohányzó orvosok aránya 12-40\% között volt [34]. Azaz a magyar háziorvosok dohányzási rátája nemzetközi összehasonlításban is kedvező.

Az alkohol világszerte az egyik legnépszerúbb élvezeti cikk, túlzott fogyasztása azonban az egyik legjelentősebb egészségromboló magatartásforma, negatív szociális és társadalmi hatásokkal. Magyarországon különösen komoly probléma a túlzott alkoholfogyasztás: az OECD felmérése alapján a 11,1 liter/fó/év elfogyasztott alkoholmennyiséggel 2016-ban a kilencedik legnagyobb alkoholfogyasztó ország voltunk [35]. A témával foglalkozó felmérések kapcsán figyelembe kell venni, hogy az önbevallásos adatok, tekintettel a téma érzékeny voltára, vélhetően alábecsülik a valódi értékeket. Vizsgálatunkban is megfigyelhető, hogy az alkoholfogyasztással kapcsolatos kérdésekre adott válaszok száma mintegy 20\%kal alacsonyabb volt. Az ELEF 2014 adatai szerint a magyar lakosság mintegy 5\%-a számított nagyivónak. Vizsgálatunkban a válaszadók 5\%-a tekinthető nagyivónak. A részt vevő háziorvosok 13\%-a absztinens, azaz saját bevallása szerint egyáltalán nem szokott alkoholtartalmú italokat inni, míg a lakosság esetén ez az arány körülbelül 25\% [31]. Megállapítható, hogy a vizsgálatban részt vevő háziorvosok körében az alkoholfogyasztás gyakorisága sajnálatos módon meghaladja az átlagpopuláció egyébként sem csekély fogyasztását. Egy brit felmérésben a válaszadók 53\%-a fogyasztott legalább hetente két alkalommal alkoholt, 27\%-a fogyasztott egy alkalommal háromnál több egység alkoholt, és 5\%-a volt tekinthető alkoholfüggőnek; a dán orvosok közel 19\%-ánál fordultak elő fokozott rizikót jelentő alkoholfogyasztási szokások [14, 36]. Azaz nemzetközi összehasonlításban nem tekinthetők rossznak a hazai adatok. Feltételezhető, hogy a háziorvosi hivatás önálló rizikótényező lehet a túlzott alkoholfogyasztás tekintetében.

A kezeletlen depresszió és szövődményei jelentős egészségügyi, szociális és társadalmi terhet jelentenek [37]. Hazai vizsgálatokban a depresszív kórképeknek (major depressziós epizód; dysthymia; minor depresszió) a PRIME-MD/DSM-IV. alapján meghatározott prevalenciája $12-37 \%$, önmagában a major depresszió prevalenciája 4-14\% [36, 37]. A részt vevő háziorvosok 30\%ánál fordultak elő depressziós tünetek, 5\%-uknál súlyos depressziós tünetegyüttes. Ezek az arányok meghaladják az ELEF 2014 során talált lakossági előfordulást (26\% és $3,5 \%)$ [31]. A felmérésben szereplő családorvosok körében az enyhe fokú (19\% vs. 16\%), a közepes fokú (6\% vs. $4 \%$ ) és a súlyos fokú ( $5 \%$ vs. $2 \%$ ) depressziós tünetegyüttes egyaránt szignifikánsan $(\mathrm{p}<0,05)$ gyakoribb volt, mint a 2002. évi Hungarostudy-felmérésben szereplő, nem orvos, felsőfokú végzettséggel rendelkező lakosok körében $(\mathrm{n}=417)$ (9. ábra). A súlyos fokú depressziós tünetegyüttesnek a magyar családorvosok közötti gyakoribb előfordulása kihatással van az egészségügyi ellátásra, és emiatt fontos lenne a pszichés problémákkal küzdő családorvosok szűrése, számukra kialakított autogén tréningek szervezése [38].

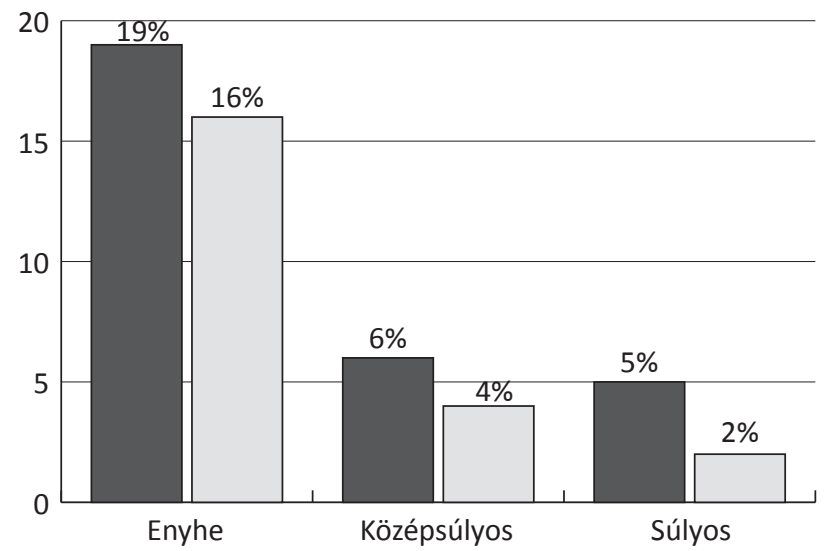

Családorvosok (saját adat) $(n=417)$

Nem orvos felsőfokú végzettségúek (Hungarostudy) $(n=489)$

9. ábra A depresszió előfordulása a családorvosok és a nem orvos felső fokú végzettségűek körében $(\mathrm{p}<0,05)$

Az egészségügyi dolgozók kiégését befolyásoló potenciális faktorokat feloszthatjuk belső, az egyénhez köthető, valamint külső, az egyéntől független, a munkakörülményekkel kapcsolatos elemekre. A személyiség és a nem kiégésben játszott szerepét számos vizsgálat elemezte [39-41]. A válaszadó háziorvosokat, különösen a férfi kollégákat (férfi: 39\% vs. nő: 32\%) a teljesítménycsökkenés érintette a leginkább, több mint egyharmaduknál jelent meg súlyos fokban. A közepes, illetve súlyos fokú deperszonalizáció szintén nagyobb mértékben érintette a férfi válaszadókat, míg a súlyos fokú emocionális kimerülés a háziorvosnőkre jellemző inkább. Mindhárom dimenzióban igen gyakori a legalább közepes fokú (3254\%) kiégés mértéke. Egy 2008. évi, 12 országra kiterjedő összehasonlító vizsgálat alapján a súlyos fokú érzelmi kimerülés előfordulása 43\% (15-68\%) volt, súlyos deperszonalizáció 35\%-ban (12-73\%), súlyos fokú teljesítménycsökkenés 32\%-ban (12\%-93\%) fordult elő. A kutatásban Magyarország is részt vett, a következő hazai eredmények születtek: érzelmi kimerülés: 36,8\%, deperszonalizáció: $35,6 \%$, teljesítménycsökkenés: 26,4\% [16]. A magyar háziorvosok kiégésszintje felmérésünk alapján hasonló az Európa más országaiban mért adatokhoz, azonban a hazánkban praktizáló családorvosok fóleg a súlyos fokú teljesítményvesztéssel és a külföldi kollégáikhoz képest kedvező súlyos fokú deperszonalizációs adatokkal tûnnek ki az összehasonlításból. A legfrissebb hazai, reprezentatív, orvosok körében végzett felmérés alapján szintén a súlyos fokú teljesítménycsökkenés fordult elő a legnagyobb arányban (42\%) [16, 41-47] (2. táblázat). A hazai háziorvosokra jellemző nagyfokú teljesítményvesztés legfóképpen azért adhat okot aggodalomra, mivel jelentős negatív hatással van a betegellátás színvonalára.

A kiégés prevalenciájának csökkentése a háziorvosok körében nem pusztán a kollégák mentálhigiénés védelme érdekében kiemelt jelentőségű, hanem közvetett mó- 
A súlyos fokú kiégés prevalenciájának nemzetközi összehasonlítása a háziorvosok körében [16, 41-47]

\begin{tabular}{llll}
\hline & $\begin{array}{l}\text { Súlyos fokú } \\
\text { emocionális } \\
\text { kimerülés }\end{array}$ & $\begin{array}{l}\text { Súlyos fokú } \\
\text { deperszo- } \\
\text { nalizáció }\end{array}$ & $\begin{array}{l}\text { Súlyos fokú } \\
\text { teljesítmény- } \\
\text { csökkenés }\end{array}$ \\
\hline Saját vizsgálat & $25 \%$ & $20 \%$ & $34 \%$ \\
EGPRN-átlag, 2008 & $43 \%$ & $35 \%$ & $32 \%$ \\
Magyar családorvosok, 2008 & $36,8 \%$ & $35,6 \%$ & $26,4 \%$ \\
Magyar orvosok, 2018 & $23,2 \%$ & $18,1 \%$ & $42 \%$ \\
Francia családorvosok & $24 \%$ & $27,3 \%$ & $13,3 \%$ \\
Német családorvosok & $34,1 \%$ & $29 \%$ & $21,5 \%$ \\
Szerb családorvosok & $29,7 \%$ & $25,7 \%$ & $37,8 \%$ \\
Kínai családorvosok & $24,8 \%$ & $6,2 \%$ & $34 \%$ \\
\hline
\end{tabular}

EGPRN = Európai Háziorvosi Kutatói Hálózat

don, a betegellátás színvonalának növelése révén, össztársadalmi érdek.

A rendszeres testmozgás kedvező hatással van az egészségi állapotra, a kiégés megelőzésében, kezelésében és a rehabilitáció során egyaránt komoly szerepe van. A WHO ajánlása alapján az egészségre gyakorolt kedvező hatások eléréséhez legalább heti 150 perc mérsékelt vagy 75 perc intenzív testmozgás, vagy a kettő ezzel egyenértékű kombinációja, valamint heti két napon legalább 10 percig tartó izomerősítő testmozgás szükséges [48]. A vizsgálatban részt vevő háziorvosok alig több mint egynegyede sportol hetente többször, míg egyötödük egyáltalán nem vagy csak nagyon ritkán végez aktív testmozgást. A nemek tekintetében nem találtunk érdemi eltérést. Egy hazai reprezentatív felmérés alapján csupán minden nyolcadik magyar végzett az aktuális WHOajánlásnak megfelelő testmozgást, és a férfiakra a nőknél nagyobb fizikai aktivitás volt jellemző. A jónak ítélt jövedelmi helyzet kedvezőbb a rendszeres fizikai aktivitás szempontjából [31]. A vizsgálatban részt vevő háziorvosok a lakossági átlagnál nagyobb hangsúlyt fektetnek a rendszeres testmozgásra. A brit orvosok mintegy fele végez rendszeres testmozgást, ír kollégáik egyötöde végez rendszeres aktív sporttevékenységet, míg közel egynegyedük inaktív. A brazil háziorvosok 47\%-ára jellemző a mérsékelt intenzitású fizikai aktivitás [9, 15, 49].

\section{Következtetés}

Napjaink jelentős kihívása a magas színvonalú, mindenki számára elérhető alapellátás biztosítása. Ehhez megfelelő számú, jól felkészített, motivált és jó egészségi állapotú háziorvosra van szükség. Ez a jelenlegi kollégák megtartásával, valamint - vonzó perspektíva biztosítása révén az újabb generációk háziorvosi pálya felé történő vonzásával valósítható meg. Ennek része a háziorvosok megfelelő testi, lelki, szellemi egészségének megőrzése, gondozása. A háziorvosok az egészségügyi ellátórendszer „tartópillérei”, így komplex egészségvédelmük nemcsak személyes, de össztársadalmi érdek is.
Anyagi támogatás: A közlemény megírása, illetve a kapcsolódó kutatómunka anyagi támogatásban nem részesült.

Szerzői munkamegosztás: M. A., T. P.: A téma felvetése, a cikk megírásának kezdeményezése. M. A., V. A., H. Cs., Cs. D., K. L., T. P.: A kézirat elkészítése. A cikk végleges változatát valamennyi szerző elolvasta és jóváhagyta.

Érdekeltségek: A szerzőknek nincsenek érdekeltségeik.

\section{Irodalom}

[1] Sas G. Doctor, does your heart ever hurt? [Doktor Úr, a maga szíve sose fáj?] Elitmed.hu, 2013. Available from: http://www. elitmed.hu/ilam/placebo_kulonszam/doktor_ur_a_maga_ szive_sose_faj_11743/[accessed: November 12, 2018]. [Hungarian]

[2] Györffy Z, Molnár R, Somorjai N. Health status and well-being of health care workers in Hungary: a literature review. [Gyógyítók helyzete és egészsége - a magyarországi vizsgálatok szakirodalmi áttekintése.] Mentálhig Psychosom. 2012; 13: 107126. [Hungarian]

[3] Kringos DS, Boerma W, van der Zee J, et al. Europe's strong primary care systems are linked to better population health but also to higher health spending. Health Aff. 2013; 32: 686-694.

[4] Starfield B. Primary care: an increasingly important contributor to effectiveness, equity, and efficiency of health services. SESPAS report 2012. Gac Sanit. 2012; 26(Suppl 1): 20-26.

[5] Lalonde M. A new perspective on the health of Canadians. A working document. Government of Canada, Ottawa, 1974.

[6] Healthy People 2010 Final Review. National Center for Health Statistics, Hyattsville, MD, 2012.

[7] Statistical Mirror: Hungarian Central Statistical Office. Health status and health behavior, 2016-2017. [Statisztikai Tükör: Egészségi állapot és egészségmagatartás, 2016-2017.] Központi Statisztikai Hivatal, Budapest, 2018. [Hungarian]

[8] Varsányi P, Vitrai J. (eds.) National Health Promotion Insitute. Health Report 2016. Informations to identify the target areas for public health interventions based on analysis of non-communicable diseases and health behavior indicators. [Egészségjelentés 2016: Információk a népegészségügyi beavatkozások célterületeinek azonosításához a nem fertőző betegségek és az egészségmagatartási mutatók elemzése alapján.] Nemzeti Egészségfejlesztési Intézet, Budapest, 2017. [Hungarian]

[9] Mittal TK, Cleghorn CL, Cade JE, et al. A cross-sectional survey of cardiovascular health and lifestyle habits of hospital staff in the UK: do we look after ourselves? Eur J Prev Card. 2018; 25: 543550 .

[10] Pardo A, McKenna J, Mitjans A, et al. Physical activity level and lifestyle-related risk factors from Catalan physicians. J Phys Act Health 2014; 11: 922-929.

[11] Faggiano P, Temporelli PL, Zito G, et al. Cardiovascular risk profile and lifestyle habits in a cohort of Italian cardiologists. Results of the SOCRATES survey (Survey on cardiac risk profile and lifestyle habits in a cohort of Italian cardiologists). [Profilo di rischio cardiovascolare e stili di vita in una coorte di cardiologi Italiani. Risultati della survey SOCRATES.] Monaldi Arch Chest Dis. 2013; 80: 118-125. [Italian]

[12] Hou L, Jin X, Ma J, et al. Perception and self-management of hypertension in Chinese cardiologists (CCHS): a multicenter, large-scale cross-sectional study. BMJ Open 2019; 9: e029249.

[13] Raag M, Pärna K. Cigarette smoking and smoking-attributable diseases among Estonian physicians: a cross-sectional study. BMC Public Health 2018; 18: 194 
[14] Medisauskaite A, Kamau C. Does occupational distress raise the risk of alcohol use, binge-eating, ill health and sleep problems among medical doctors? A UK cross-sectional study. BMJ Open 2019; 9: e027362.

[15] O'Keeffe A, Hayes B, Prihodova L. "Do as we say, not as we do?" The lifestyle behaviours of hospital doctors working in Ireland: a national cross-sectional study. BMC Public Health 2019; 19: 179 .

[16] Soler JK, Yaman H, Esteva M, et al. Burnout in European family doctors: the EGPRN study. Fam Pract. 2008; 25: 245-265.

[17] West CP, Dyrbye LN, Shanafelt TD. Physician burnout: contributors, consequences and solutions. J Intern Med. 2018; 283: 516-529

[18] Peckham C. Physician burnout: it just keeps getting worse. Burnout and happiness in physicians: 2013 vs 2015. Medscape Fam Med. January 26, 2015. Available from: https://www.medscape.com/viewarticle/838437_print [accessed: January 29, 2020].

[19] Rodrigues H, Cobucci R, Oliveira A, et al. Burnout syndrome among medical residents: a systematic review and meta-analysis. PLoS ONE 2018; 13: e0206840

[20] Fernandes LS, Nitsche MJ, Godoy I. Association between burnout syndrome, harmful use of alcohol and smoking in nursing in the ICU of a university hospital. Cien Saude Colet. 2018; 23: 203-214.

[21] McCain RS, McKinley N, Dempster M, et al. A study of the relationship between resilience, burnout and coping strategies in doctors. Postgrad Med J. 2018; 94: 43-47.

[22] Tyssen R. What is the level of burnout that impairs functioning? J Int Med. 2018; 283: 594-596.

[23] Dewa CS, Loong D, Bonato S, et al. The relationship between physician burnout and quality of healthcare in terms of safety and acceptability: a systematic review. BMJ Open 2017; 7: e015141.

[24] Hungarian Central Statistical Office. Social situation outlook 2010. [Társadalmi helyzetkép 2010.] Központi Statisztikai Hivatal, Budapest, 2011. [Hungarian]

[25] Abuissa H, Lavie C, Spertus J, et al. Personal health habits of American cardiologists. Am J Cardiol. 2006; 97: 1093-1096.

[26] Frank E, Segura C. Health practices of Canadian physicians. Can Fam Phys. 2009; 55: 810-811.e7.

[27] Kiss I, Barna I, Daiki T, et al. Results of the comprehensive health screening of Hungary (MÁESZ) in 2016 and comparative results of 2010-2016. [„Magyarország átfogó egészségvédelmi szứrőprogram"-jának (MÁESZ) 2016. évi és 2010-2016 közötti összefoglaló adatai. Prevenció, kockázatfelmérés és egészségmegőrzés - a szüroovizsgálatok jelentősége és haszna.] Lege Artis Med. 2017; 27: 25-30. [Hungarian]

[28] IDF Diabetes Atlas. 9th edition 2019. International Diabetes Federation, Brussels, 2020.

[29] WHO global report on trends in tobacco smoking 2000-2025. WHO Press, Geneva, 2015

[30] Neuberger M. Tobacco control: prevention and cessation in Europe. MEMO 2019; 12: 156-161.

[31] Hungarian Central Statistical Office. Results of the European Public Health Survey in 2014. Summary data. [A 2014-ben végrehajtott Európai lakossági egészségfelmérés eredményei. Összefoglaló adatok.] Központi Statisztikai Hivatal, Budapest, 2018. [Hungarian]

[32] Jankowski M, Kaleta D, Zgliczyński WS, et al. Cigarette and e-cigarette use and smoking cessation practices among physicians in Poland. Int J Environ Res Public Health 2019; 16: 3595.
[33] Al-Hagabani MA, Khan MS, Al-Hazmi AM, et al. Smoking behavior of primary care physicians and its effect on their smoking counseling practice. J Family Med Prim Care 2020; 9: 10531057.

[34] Smith DR, Leggat PA. An international review of tobacco smoking in the medical profession: 1974-2004. BMC Public Health 2007; 7: 115 .

[35] OECD Data. Alcohol consumption. Available from https:// data.oecd.org/healthrisk/alcohol-consumption.htm [accessed: June 2, 2020].

[36] Pedersena AF, Sørensen JK, Bruun NH, et al. Risky alcohol use in Danish physicians: associated with alexithymia and burnout? Drug Alcohol Depend. 2016; 160: 119-126.

[37] Torzsa P, Hargittay Cs, Kalabay L. The importance of anxiety and depression in family practice. [A szorongás és a depresszió jelentősége a családorvosi gyakorlatban.] Neuropsychopharmacol Hung. 2017; 19: 137-146. [Hungarian]

[38] Rihmer Z, Gonda X, Eöry A, et al. Screening of depression in primary care in Hungary and its importance in suicide prevention. [A depresszió szúrése az alapellátásban Magyarországon és ennek jelentősége az öngyilkosság megelőzésében.] Psychiatr Hung. 2012; 27: 224-232. [Hungarian]

[39] Györffy Zs, Dweik D, Girasek E. Workload, mental health and burnout indicators among female physicians. Hum Resour Health 2016; 14: 12.

[40] Győrffy Zs, Ádám S. Changes of health status, work stress and burnout in the medical profession. [Az egészségi állapot, a munkastressz és a kiégés alakulása az orvosi hivatásban.] Szociol Szle. 2004; 11(3): 107-127. [Hungarian]

[41] Ádám Sz, Torzsa P, Győrffy Zs, et al. Frequent high-level burnout among general practitioners and residents. [Gyakori a magas fokú kiégés a háziorvosok és háziorvosi rezidensek körében.] Orv Hetil. 2009; 150: 317-323. [Hungarian]

[42] Győrffy Zs, Girasek E. Burnout among Hungarian physicians. Who are the most at risk? [Kiégés a magyarországi orvosok körében. Kik a legveszélyeztetettebbek?] Orv Hetil. 2015; 156: 564570. [Hungarian]

[43] Picquendar G, Guedon A, Moulinet F, et al. Influence of medical shortage on GP burnout: a cross-sectional study. Fam Pract. 2019; 36: 291-296.

[44] Dreher A, Theune M, Kersting C, et al. Prevalence of burnout among German general practitioners: comparison of physicians working in solo and group practices. PLoS ONE 2019; 14: $\mathrm{e} 0211223$

[45] Stanetic KD, Savic SM, Racic M. The prevalence of stress and burnout syndrome in hospital doctors and family physicians. Med Pregl. 2016; 69: 356-365.

[46] Gan Y, Jiang H, Li L, et al. Prevalence of burnout and associated factors among general practitioners in Hubei, China: a crosssectional study. BMC Public Health 2019; 19: 1607.

[47] Győrffy Zs. Burnout and resilience among Hungarian physicians. [Kiégés és reziliencia (rugalmas ellenállás) a magyarországi orvosok körében.] Orv Hetil. 2018; 160: 112-119. [Hungarian]

[48] Global recommendations on physical activity for health. WHO Press, Geneva, 2010

[49] Hidalgo KD, Mielke GI, Parra DC, et al. Health promoting practices and personal lifestyle behaviors of Brazilian health professionals. BMC Public Health 2016; 16: 1114.

(Mohos András dr., Szeged, Székely sor 13/A, 6726 e-mail: mohosandris@gmail.com)

A cikk a Creative Commons Attribution 4.0 International License (https://creativecommons.org/licenses/by/4.0/) feltételei szerint publikált Open Access közlemény, melynek szellemében a cikk bármilyen médiumban szabadon felhasználható, megosztható és újraközölhetö, feltéve, hogy az eredeti szerző és a közlés helye, illetve a CC License linkje és az esetlegesen végrehajtott módosítások feltüntetésre kerülnek. (SID_1) 